Article

\title{
Exploring the Effect of Dehydration on Water Migrating Property and Protein Changes of Large Yellow Croaker (Pseudosciaena crocea) during Frozen Storage
}

\author{
Mingtang Tan ${ }^{1}(\mathbb{D})$ and Jing Xie ${ }^{1,2,3,4, *(\mathbb{D})}$ \\ 1 College of Food Science and Technology, Shanghai Ocean University, Shanghai 201306, China; \\ mingtang120@163.com \\ 2 Shanghai Engineering Research Center of Aquatic Product Processing \& Preservation, \\ Shanghai 201306, China \\ 3 Professional Technology Service Platform on Cold Chain Equipment Performance and Energy Saving \\ Evaluation, Shanghai 201306, China \\ 4 National Experimental Teaching Demonstration Center for Food Science and Engineering, \\ Shanghai 201306, China \\ * Correspondence: jxie@shou.edu.cn; Tel.: +86-02161900391
}

check for updates

Citation: Tan, M.; Xie, J. Exploring the Effect of Dehydration on Water Migrating Property and Protein Changes of Large Yellow Croaker (Pseudosciaena crocea) during Frozen Storage. Foods 2021, 10, 784. https:// doi.org/10.3390/foods10040784

Academic Editor: Joaquina Pinheiro

Received: 10 March 2021

Accepted: 3 April 2021

Published: 6 April 202

Publisher's Note: MDPI stays neutra with regard to jurisdictional claims in published maps and institutional affiliations.

Copyright: (c) 2021 by the authors. Licensee MDPI, Basel, Switzerland. This article is an open access article distributed under the terms and conditions of the Creative Commons Attribution (CC BY) license (https:/ creativecommons.org/licenses/by/ $4.0 /)$

\begin{abstract}
This study aimed to explore the effect of dehydration on the water migrating property and protein changes of large yellow croaker during frozen storage. A freeze-dryer was used to accelerate experiments, which was isolated from oxygen and excluded the effects of protein oxidation. After dehydration time $(3,9,18$, and $30 \mathrm{~h})$ for both fast- and slow-freezing samples, the results showed that the ice sublimation of samples containing small ice crystals was faster than that of samples containing large ice crystals in the early stages of dehydration, but in the latest stage, there was an opposite trend. The results indicated that dehydration reduced the water freedom degrees and waterprotein interaction. At the same time, dehydration had a significant effect on protein secondary and tertiary structures. The significant increase in surface hydrophobicity and particle size indicated that dehydration exacerbated myofibrillar protein aggregation. The $\Delta \mathrm{H} 1$ values (from 1.275 to $0.834 \mathrm{~J} / \mathrm{g}$ for slow-freezing group and from 1.129 to $0.855 \mathrm{~J} / \mathrm{g}$ for fast-freezing group) decreased gradually as the dehydration time extended, indicating the decrease in protein thermal stability. Additionally, significant protein degradation occurred when the water content of the sample decreased to a certain level. This study showed that ice crystal size had an important effect on the rate of ice sublimation, and the occurrence of dehydration during frozen storage accelerated the water loss and the decrease in protein stability.
\end{abstract}

Keywords: large yellow croaker (Pseudosciaena crocea); ice crystal; dehydration; water migrating property; protein changes

\section{Introduction}

Freezing may cause a variety of adverse effects on aquatic products, such as freeze concentration, mechanical damage, freezer burn, and recrystallization [1]. It is usually accompanied by a decrease in quality, including oxidation of proteins and lipids, deterioration of texture, and a decrease in water content [2]. The formation of large ice crystals and uneven distribution in aquatic products tissue can cause poor organoleptic quality and loss of nutrients, such as deterioration of drip loss and softening [3]. In particular, product dehydration during frozen storage leads to weight loss and the loss of valuable nutrients which might result in the detriment of both businesses and consumers.

The majority of water is trapped in the protein-dense networks of muscle structure, which accounts for about $65 \%$ to $80 \%$ of muscle tissue [4]. When the ice vapor pressure on the surface of the product is lower than that of the surrounding air during frozen storage, the ice sublimates from the surface of the product to its surrounding environment, resulting 
in dehydration, which is also known as freezer burn if the dehydration is serious [5]. This phenomenon can occur from the surface of the product to its core. The water migration and the interaction between water and protein of lamb meat during $35^{\circ} \mathrm{C}$ air drying were investigated by Rao et al. [6]. The results indicated that bound water, which was tightly bound to protein macromolecules $\left(\mathrm{T}_{2 \mathrm{~b}}\right)$, and immobilized water that was located in the myofibrillar protein network $\left(\mathrm{T}_{21}\right)$ played an important role in the water migration of lamb during air drying, and besides, the denaturation of myosin may lead to water migration from myofibrils to the space between myofibrils. Likewise, the decrease in water content of the sample due to water evaporation could also result in protein denaturation [6]. Thus, there is a strong relationship between the water content in frozen foods and its degree of protein denaturation. In addition to the occurrence of dehydration during frozen storage, there is also ice recrystallization [3] and protein oxidation and denaturation [7] caused by frozen storage, making it impossible to directly prove the specific effect of dehydration on protein denaturation.

Freeze drying is a dehydration process by direct sublimation of ice crystals from a frozen product [8]. In order to investigate the effect of ice crystal morphology on the efficiency of dehydration, Jin et al. [9] added biogenic ice nucleation proteins (INPs) to sucrose solution in a freeze-dryer, and the results indicated that the ice crystals formed by INPs were larger in size and had lamellar structure, which was less obstructive to water vapor flow and more conducive to the occurrence of dehydration of frozen products. On the contrary, the literature suggests that in frozen muscle tissue, small crystals with a higher surface free energy and thermodynamic instability are more potent in melting than large crystals at lower temperatures [10,11]. The evidence for this relationship between ice crystals size and dehydration remains inconclusive. Consequently, it is necessary to evaluate the effect of ice crystal size on dehydration. Further, we wished to confirm the effect of dehydration on the water migrating property and protein changes of samples while excluding the changes such as protein oxidation and ice recrystallization caused by prolonged frozen storage. The significant difference in the size of ice crystals formed by refrigerator freezer and spiral freezer had been confirmed in a previous experiment.

For this purpose, this work used a freeze-dryer to accelerate the ice sublimation of large yellow croakers during frozen storage. Samples containing different ice crystal sizes were observed to determine their water migrating property and their protein changes, and an attempt was made to describe the relationship between dehydration and protein denaturation. The purpose of this study was to explore the mechanism of how product quality is affected by dehydration during frozen storage and to understand the effect of ice crystal size on dehydration of aquatic products, which will help to slow down quality degradation due to dehydration during frozen storage of aquatic products.

\section{Materials and Methods}

\subsection{Sample Processing}

Live large yellow croakers (Pseudosciaena crocea) (480-500/g, about $30 \mathrm{~cm}$ in length) purchased from a seafood port in Shanghai, China, were shipped to the laboratory and then wrapped in ice to death. The remaining surface water, blood, and slime on the samples were dried by paper towel. Before being assigned to one of the two freezing treatments, namely slow freezing $\left(-18{ }^{\circ} \mathrm{C}\right.$ refrigerator) and fast freezing (spiral freezer with $6.67 \mathrm{~m} / \mathrm{s}$ wind speed), the samples were packed in sealed bags to prevent the water loss of samples during freezing due to the wind speed. When the core temperature of these samples reached $-18{ }^{\circ} \mathrm{C}$, the frozen samples removed from the sealed bags were subsequently loaded on the shelf of a freeze-dryer to simulate the crystalized ice sublimation of large yellow croakers during frozen storage.

In this study, the parameters adopted for the freeze-dryer were as follows: (1) the vacuum in the drying chamber was controlled at 200-300 ubar, (2) the temperature of the cold trap was $-40{ }^{\circ} \mathrm{C}$, and (3) the shelf temperature was controlled at $-18{ }^{\circ} \mathrm{C}$. The fast-freezing samples were placed in a freeze-dryer for $3,9,18$, and $30 \mathrm{~h}$ and were named 
F3, F9, F18, and F30, respectively. Similarly, these slow-freezing samples treated by the freeze-dryer were named S3, S9, S18, and S30. Subsequently, all samples were transferred to vacuum bags for maximum isolation from surrounding air. Finally, samples were stored in $\mathrm{a}-80{ }^{\circ} \mathrm{C}$ freezer (to reduce the effect of ice recrystallization), and all testing was completed within two weeks. The back muscle of the fish was used for the determination of all indicators.

\subsection{Measurement of Weight Loss and Water Content}

The thawed sample muscle was weighed before dehydration treatment $\left(W_{1}\right)$, and the sample was weighed again at the end of treatment $\left(W_{2}\right)$. Weight loss was calculated as shown in Equation (1):

$$
\text { Weight loss } / \%=\frac{W_{1}-W_{2}}{W_{1}} \times 100
$$

The water content of large yellow croakers was assessed with a water tester (HX-Q10, Shanghai Huxi Analytical Instrument Factory Co., Ltd., Shanghai, China). Five grams of thawed sample muscle $\left(W_{3}\right)$ was heated at $105^{\circ} \mathrm{C}$ until the weight change was less than $0.001 \mathrm{~g}$ in $1 \mathrm{~min}$; then, the sample was removed and the water content ( $\mathrm{g}$ of water per $100 \mathrm{~g}$ of sample) was calculated according to the difference in mass before and after $\left(W_{4}\right)$ drying as shown in Equation (2):

$$
\text { Water content } / \frac{g}{100 g}=\frac{W_{3}-W_{4}}{W_{3}} \times 100
$$

\subsection{Measurement of Unfrozen Water Content}

The unfrozen water (UFW) content was determined using a differential scanning calorimeter (DSC-8500, PerkinElmer, Norwalk, USA) according to the method of Li et al. [12] with some modifications. About $15 \mathrm{mg}$ of the frozen sample muscle was placed in a tightly sealed aluminum pan. It was left at a starting temperature of $-40{ }^{\circ} \mathrm{C}$ for $2 \mathrm{~min}$ and then heated to a final temperature of $35^{\circ} \mathrm{C}$ at a rate of $10^{\circ} \mathrm{C} / \mathrm{min}$. The UFW content $(\mathrm{g} / 100 \mathrm{~g})$ was calculated as follows:

$$
\mathrm{UFW}=\left(W-\frac{\Delta H}{\Delta H_{0}} \times 100\right)
$$

where $\Delta H$ is the heat of fusion for the samples, $\mathrm{J} / \mathrm{g} ; \Delta H_{0}$ indicates the heat of fusion for pure water at $0{ }^{\circ} \mathrm{C}, 333.88 \mathrm{~J} / \mathrm{g}$; and $W$ is the water content in the sample, which was determined using the initial method, $\mathrm{g} / 100 \mathrm{~g}$.

\subsection{Low-Field Nuclear Magnetic Resonance (LF-NMR) and Magnetic Resonance Imaging (MRI)}

The water distribution and states of large yellow croakers were determined by a MesoMR23-060H.I LF-NMR analyzer (Niumag Corporation, Shanghai, China) according to a previously described method [13,14]. Thawed samples $(2.0 \mathrm{~cm} \times 2.0 \mathrm{~cm} \times 1.0 \mathrm{~cm})$ were taken from the dorsal muscles of the croaker, dried to remove surface water, and wrapped with fresh-keeping film. Each sample was examined in a $70 \mathrm{~mm}$ diameter cylindrical probe with a working temperature of $32{ }^{\circ} \mathrm{C}$. Acquisition parameters were as follows: receiver bandwidth frequency $(\mathrm{SW})=100 \mathrm{kHz}$; analog gain $(\mathrm{RG} 1)=20.0 \mathrm{dp} ; \mathrm{P} 1=19.00 \mu \mathrm{s}$; digital gain $(\mathrm{DRG} 1)=6$; $\mathrm{TD}=400,068$; preamplifier gain $(\mathrm{PRG})=1$; duration between successive scans $(\mathrm{TW})=2000 \mathrm{~ms}$; number of the scans $(\mathrm{NS})=4$; P2 $=38.00 \mu \mathrm{s}$; time echo $(\mathrm{TE})=0.500 \mathrm{~ms}$; and $\mathrm{NECH}=8000$. The MRI imaging software and MSE spin-echo imaging sequence acquisition were used to generate the proton density weighted images of the samples.

\subsection{Total Sulfhydryl (SH) Content}

To extract myofibrillar proteins (MFPs) from fish, $2 \mathrm{~g}$ of thawed croaker muscle was homogenized in $20 \mathrm{~mL}$ of buffer $\mathrm{A}(50 \mathrm{mmol} / \mathrm{L} \mathrm{KCl}, 20 \mathrm{mmol} / \mathrm{L}$ Tris-maleate, $\mathrm{pH} 7.0)$ using a homogenizer, followed by centrifugation at $10,000 \times \mathrm{g}$ for $15 \mathrm{~min}$ at $4{ }^{\circ} \mathrm{C}$. The protein 
precipitate was then repeatedly centrifuged as in the previous step. Finally, the obtained precipitate was mixed with $20 \mathrm{~mL}$ of buffer $\mathrm{B}(0.6 \mathrm{~mol} / \mathrm{L} \mathrm{KCl}, 20 \mathrm{mmol} / \mathrm{L}$ Tris-maleate, $\mathrm{pH}$ 7.0), homogenized, extracted at $4{ }^{\circ} \mathrm{C}$ for $3 \mathrm{~h}$, and then centrifuged at $10,000 \times g$ for $15 \mathrm{~min}$ at $4^{\circ} \mathrm{C}$. The obtained supernatant was the MFP solution required for this experiment.

The total SH content of the MFP was measured using the total SH measurement kit (Nanjing Jiancheng Bioengineering Institute, Nanjing, China), and results were expressed as $\mu \mathrm{mol} / \mathrm{g}$ prot.

\subsection{Determination of MFP Aggregation \\ 2.6.1. Surface Hydrophobicity}

The surface hydrophobicity $\left(\mathrm{S}_{0}-\mathrm{ANS}\right)$ of MFP was determined using ANS (8-anilino1-naphthalene sulfonate) as a fluorescence probe according to Nian et al. [15]. The MFP was diluted to $0.2,0.4,0.8$, and $1.0 \mathrm{mg} / \mathrm{mL}$ protein solution with $20 \mathrm{mM}$ PBS (pH 6.7, $0.6 / \mathrm{M} \mathrm{NaCl}$ ). Subsequently, $4 \mathrm{~mL}$ protein solutions were each added to $20 \mu \mathrm{L} 20 \mathrm{mM}$ PBS (containing $8 \mathrm{mM}$ ANS, pH 7.0) and allowed to stand for $10 \mathrm{~min}$ at room temperature $\left(25{ }^{\circ} \mathrm{C}\right)$ under dark conditions. $\mathrm{S}_{\mathrm{o}}$-ANS of each sample was acquired from the slope of the relative fluorescence intensity of the solution measured with an F-7100 fluorescence spectrophotometer (Hitachi Co., Tokyo, Japan) at an excitation wavelength of $390 \mathrm{~nm}$, an emission wavelength of $470 \mathrm{~nm}$, and a slit width of $10 / \mathrm{nm}$.

\subsubsection{Particle Size}

The particle size of MFP was measured using a Mastersizer 3000 (Malvern Instruments Ltd., Malvern, UK). The material refractive index and absorption coefficient were set to 1.46 and 0.001 , respectively.

\subsection{Protein Secondary Structure}

Raman spectrometer (HR800, Horiba/Jobin. Yvon, Longjumeau, France) was used to analyze the changes of protein secondary structure following the method of Zhang et al. [16]. The thawed samples were transferred to a glass slide for measurement. The parameters were as follows: excitation wavelength of $532 \mathrm{~nm}$, scanning range $400-3800 \mathrm{~cm}^{-1}$, instrument power of $100 \mathrm{~mW}$, resolution of $2 \mathrm{~cm}^{-1}$, exposure time of $60 \mathrm{~s}$, slit width of $200 / \mu \mathrm{m}$, raster of $600 / \mathrm{g} / \mathrm{mm}$, and number of sample scans of 3 . The spectral data were baseline corrected, smoothed, and normalized using Omnic 8.0 software (Thermal Fisher Scientific, Madison, WI, USA). Peakfit 4.12 software was used to quantify the relative content of protein secondary structure.

\subsection{Protein Tertiary Structure}

The tertiary structure of MFP solutions $(0.05 \mathrm{mg} / \mathrm{mL})$ was measured by an F-7100 fluorescence spectrophotometer. The parameters were as follows: excitation wavelength of 295/nm, excitation and emission slit widths of $5 \mathrm{~nm}$, emission spectra range 300-410/nm, scanning speed of $1200 / \mathrm{nm} / \mathrm{min}$, and PMT voltage of $400 \mathrm{~V}$.

\subsection{Protein Thermal Stability Properties}

Changes in thermal stability of proteins were measured using a differential scanning calorimeter (TA Q2000, TA Instruments, New Castle, DE, USA) as previously described by Liu et al. [17] with slight modifications. Thawed samples $(10 \mathrm{mg})$ were accurately weighed and placed in a tightly sealed aluminum pan, while a sealed empty aluminum pan was used as a control group. Samples were equilibrated at $20^{\circ} \mathrm{C}$ for $2 \mathrm{~min}$ and then heated from 20 to $100{ }^{\circ} \mathrm{C}$ at a heating rate of $5^{\circ} \mathrm{C} / \mathrm{min}$.

\subsection{Sodium Dodecyl Sulfate-Polyacrylamide Gel Electrophoresis (SDS-PAGE)}

SDS-PAGE of MFP was performed as described by Wang et al. [18]. SDS-PAGE was performed continuously on a pre-cast $12 \%$ Hepes-Tris gel, and protein standards ranging 
from 11 to $245 \mathrm{kDa}$ purchased from EZBiolab were used to determine protein molecular weight after electrophoresis.

\subsection{Statistical Analysis}

In this study, all measurements were repeated in triplicate. The results were expressed as mean \pm standard deviation. One-way ANOVA analysis and Duncan's test were performed on the experimental data using SPSS 25.0 (SPSS Inc., Chicago, IL, USA), and $p<0.05$ indicated that the means differed significantly. Pearson correlation was used to calculate linear correlations of variables between unfrozen water content and bound water, and figures were created with Origin 2018 software (OriginLab Corporation, Northampton, MA, USA).

\section{Results and Discussion}

\subsection{Weight Loss and Water Content Analysis}

The ice sublimation can be mimicked by a freeze-dryer, and Figure 1 shows the weight loss and water content of thawed large yellow croaker at different dehydration times. The weight loss of the slow-freezing group decreased more slowly than that of the fast-freezing group during the first $9 \mathrm{~h}$, but in the later stage, the slow-freezing group had more weight loss than the fast-freezing group. The same trend was also shown for the water content. The water content of the S3 group was 1.50\% higher than that of the F3 group, while the water content of the S30 group was 1.89\% lower than that of the F30 group. Compared to large ice crystals, small ice crystals with higher thermodynamic energy are more capable of sublimation at low temperatures [19]; hence, samples containing small ice crystals are more liable to cause weight loss and decrease in water content at the initial time of dehydration (Figure 2). Smaller pores were left after sublimation of small ice crystals on the sample surface; however, they are more resistant to the subsequent water vapor flow during sublimation [20]. Based on this, larger ice crystals can instead exacerbate the water loss of the sample during prolonged dehydration. It is also shown in Figure 1 that the rate of water loss gradually decreased for all samples with the extension of dehydration time, and ice crystals inside the samples covered by the surface muscles were probably not susceptible to sublimation due to the increasing mass transfer resistance. Therefore, it is essential to suppress water loss at the initial stage of frozen storage in order to obtain a higher quality product.
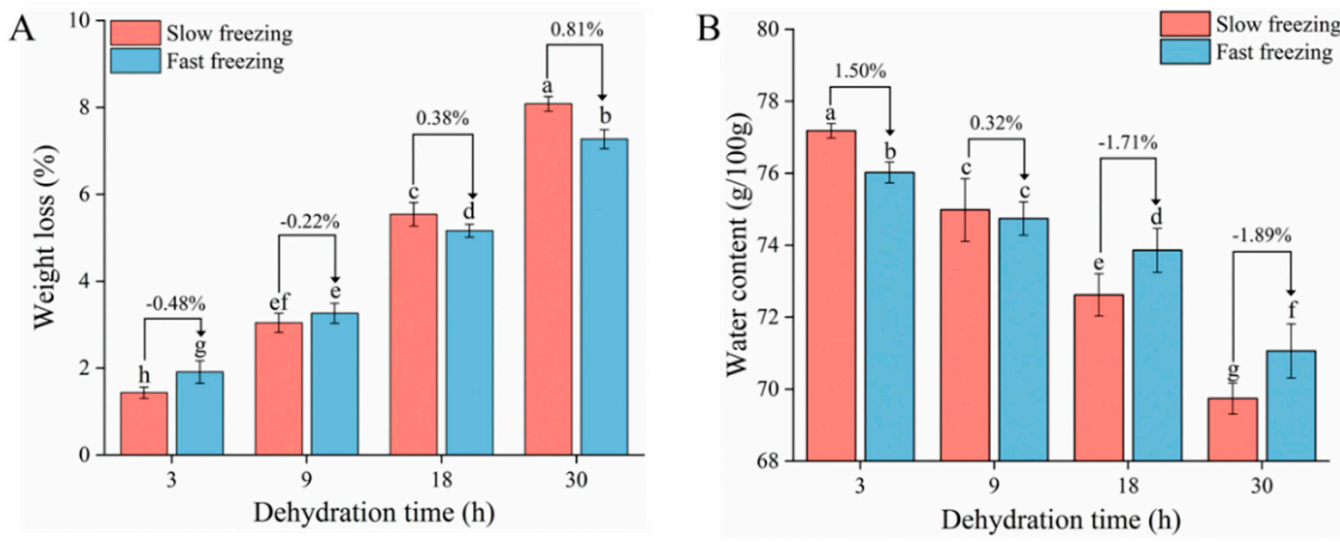

Figure 1. Effect of dehydration treatment on weight loss (A) and water content (B) of large yellow croaker. Different lowercase letters in the same index indicate significant differences $(p<0.05)$. The water content of the fresh sample (CK) was $83 \pm 0.63 \%$. 


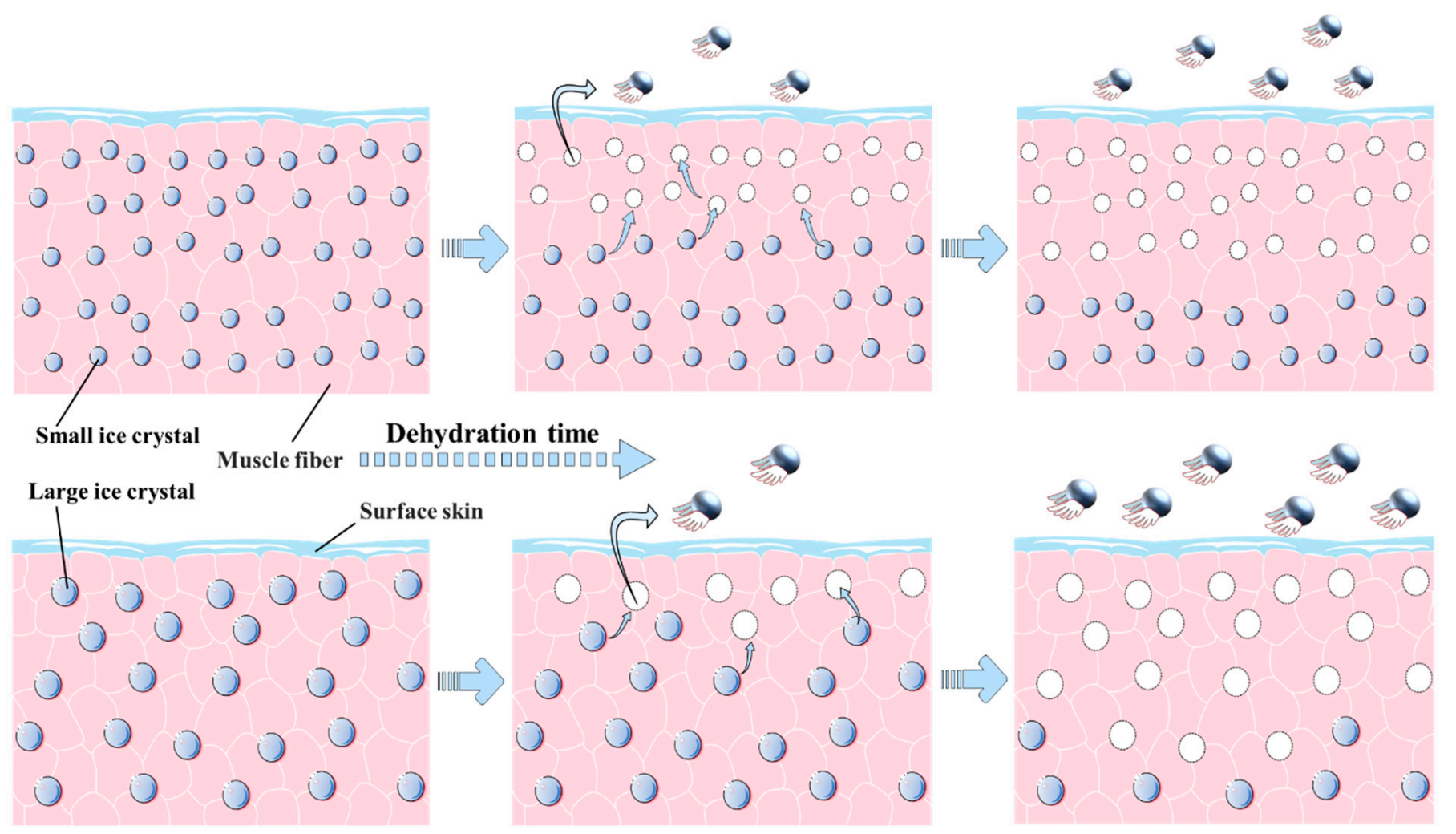

Figure 2. Schematic diagram of ice crystal sublimation during dehydration.

\subsection{Water Status Analysis}

There are three water states in thawed croaker: bound water $\left(\mathrm{T}_{2 \mathrm{~b}}\right)$, immobilized water $\left(T_{21}\right)$, and free water $\left(T_{22}\right)$. In Figure $3 A$, it can be seen that the majority of the water in these samples was immobilized water, and as the water content of samples decreased, its peak area $\left(\mathrm{A}_{21}\right)$ gradually decreased and the peak position migrated to the left, which indicated that the freedom degrees of immobilized water gradually decreased and the water was more tightly bound to non-water components [21,22]. The possible reason was ascribed to the water loss with higher freedom degrees in immobilized water during dehydration. The $\mathrm{T}_{2}$ relaxation time and peak area of the three water populations are shown in Table 1. Similarly, it was found that the decrease in water content led to a decrease in $T_{2 b}, T_{22}$, and $A_{22}$ during dehydration. However, the $A_{2 b}$ of the bound water showed an increasing trend, which was because the relaxation area, as a relative area, decreased for the other two kinds of water. Similar results were also obtained in the drying experiments of shrimp [22] and abalone [23]. The reduction of bound water, which is tightly bound to protein macromolecules, may contribute to the degradation and denaturation of muscle proteins.

The results in Table 1 indicate a decreasing trend in the unfrozen water (UFW) content as the water content of the samples decreased. The UFW in frozen aquatic products is mainly bound water that is closely attached to the polar groups on the surface of protein macromolecules [12]. Therefore, changes in bound water content due to dehydration could reflect the aggregation and conformational changes of proteins during this period [24]. In addition, the decline in UFW content occurred mainly in the late stage of dehydration. 

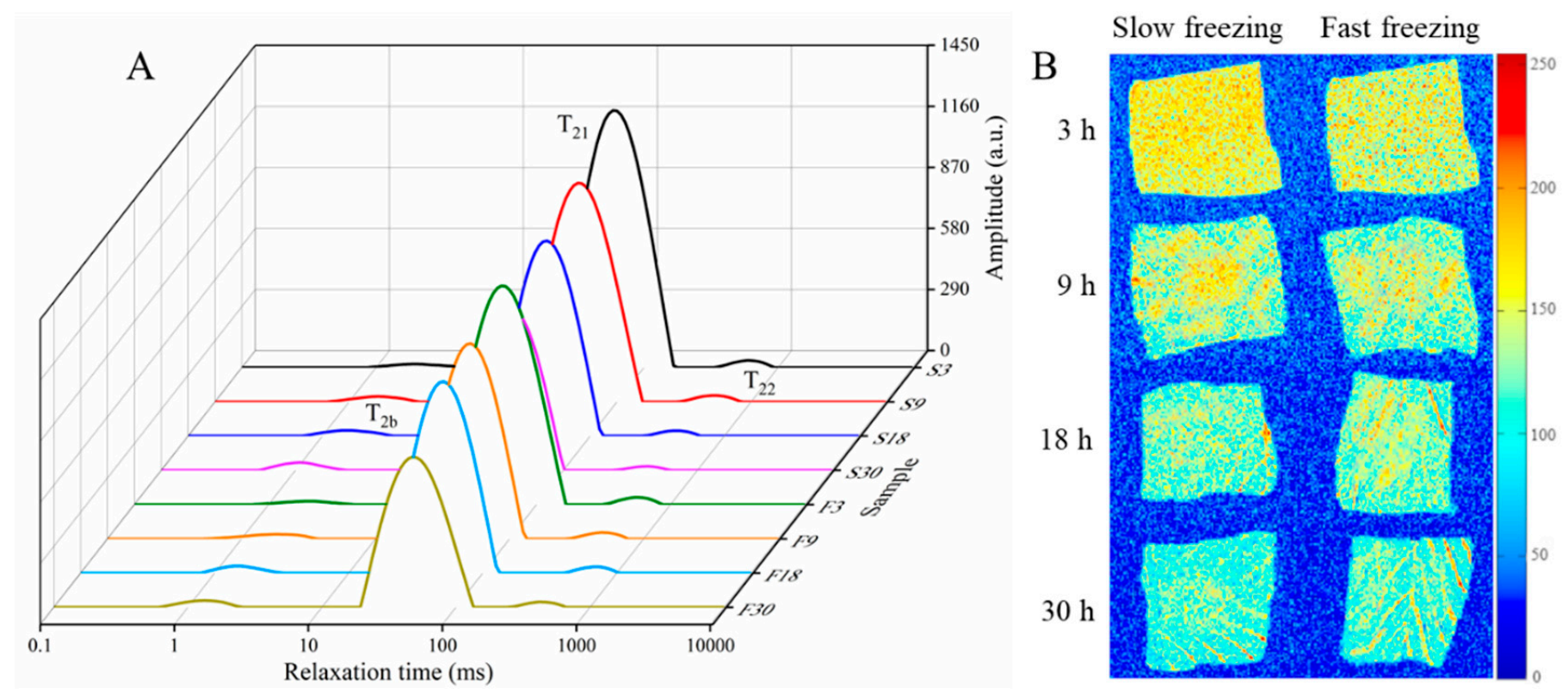

Figure 3. Transverse relaxation time $\left(\mathrm{T}_{2}\right)$ curves $(\mathbf{A})$ and MRI pseudocolor images $(\mathbf{B})$ of thawed large yellow croakers during dehydration.

Table 1. NMR parameters, unfrozen water content, and total SH content of large yellow croakers during dehydration.

\begin{tabular}{|c|c|c|c|c|c|c|c|c|}
\hline \multirow{2}{*}{ Sample } & \multicolumn{2}{|c|}{ Bound Water } & \multicolumn{2}{|c|}{ Immobilized Water } & \multicolumn{2}{|c|}{ Free Water } & \multirow{2}{*}{$\begin{array}{c}\text { UFW } \\
\text { (g/100g) }\end{array}$} & \multirow{2}{*}{$\begin{array}{l}\text { Total SH } \\
\text { Content } \\
(\mu \mathrm{mol} / \mathrm{g})\end{array}$} \\
\hline & $\mathrm{T}_{2 \mathrm{~b}}(\mathrm{~ms})$ & $A_{2 b}(1 / g)$ & $\mathrm{T}_{21}(\mathrm{~ms})$ & $A_{21}(1 / g)$ & $\mathrm{T}_{22}(\mathrm{~ms})$ & $A_{22}(1 / g)$ & & \\
\hline S3 & $1.96 \pm 0.13^{\mathrm{a}}$ & $257.11 \pm 7.98^{g}$ & $54.79 \pm 2.53^{a}$ & $21,341.01 \pm 78.38^{\mathrm{a}}$ & $622.26 \pm 74.66^{a}$ & $313.22 \pm 16.36^{a b}$ & $31.62 \pm 0.78^{a}$ & $18.15 \pm 0.26^{\mathrm{a}}$ \\
\hline S9 & $1.96 \pm 0.12^{\mathrm{a}}$ & $343.46 \pm 4.86^{f}$ & $51.11 \pm 0.49^{b}$ & $19,166.92 \pm 67.84^{b}$ & $541.59 \pm 57.91^{b}$ & $293.20 \pm 9.10^{c}$ & $28.46 \pm 0.52^{c}$ & $18.27 \pm 0.23^{a}$ \\
\hline S18 & $1.48 \pm 0.12^{b c}$ & $385.73 \pm 6.19^{\mathrm{cd}}$ & $47.69 \pm 1.28^{c}$ & $15,224.69 \pm 59.93$ ef & $439.76 \pm 30.80^{\mathrm{d}}$ & $231.89 \pm 7.47^{\mathrm{e}}$ & $23.99 \pm 0.33^{\mathrm{e}}$ & $17.98 \pm 0.21^{\mathrm{ab}}$ \\
\hline S30 & $1.12 \pm 0.14^{\mathrm{cd}}$ & $459.91 \pm 4.50^{\mathrm{a}}$ & $41.50 \pm 0.80^{\mathrm{d}}$ & $11,908.50 \pm 61.07^{\mathrm{h}}$ & $410.27 \pm 52.63^{e}$ & $164.98 \pm 11.98 \mathrm{~g}$ & $19.10 \pm 0.63 \mathrm{~g}$ & $16.84 \pm 0.17^{\mathrm{a}}$ \\
\hline F3 & $1.96 \pm 0.10^{a}$ & $246.29 \pm 2.71^{h}$ & $54.79 \pm 2.44^{\mathrm{a}}$ & $19,077.90 \pm 62.31^{b c}$ & $580.52 \pm 61.45^{\mathrm{ab}}$ & $337.16 \pm 17.29^{a}$ & $29.08 \pm 0.46^{b}$ & $18.22 \pm 0.25^{\mathrm{a}}$ \\
\hline F9 & $1.70 \pm 0.21^{a b}$ & $371.81 \pm 4.74 \mathrm{e}^{\mathrm{e}}$ & $51.11 \pm 0.99^{b}$ & $17,113.04 \pm 65.26^{d}$ & $505.26 \pm 28.38^{c}$ & $279.88 \pm 13.14^{\mathrm{cd}}$ & $28.53 \pm 0.29^{b c}$ & $18.03 \pm 0.20^{a}$ \\
\hline F18 & $1.59 \pm 0.12^{b}$ & $394.41 \pm 4.33^{c}$ & $51.11 \pm 1.56^{\mathrm{ab}}$ & $16,077.90 \pm 83.30^{\mathrm{e}}$ & $471.38 \pm 81.33^{\mathrm{cd}}$ & $263.37 \pm 20.26^{d}$ & $26.75 \pm 0.57^{\mathrm{d}}$ & $17.81 \pm 0.24^{b}$ \\
\hline F30 & $1.29 \pm 0.11^{\mathrm{c}}$ & $428.12 \pm 5.18^{b}$ & $47.69 \pm 3.27^{c}$ & $12,327.77 \pm 107.5^{g}$ & $439.76 \pm 101.26^{d}$ & $220.42 \pm 28.53$ ef & $21.04 \pm 0.70^{\mathrm{f}}$ & $17.05 \pm 0.33^{c}$ \\
\hline
\end{tabular}

Values are mean \pm standard deviation. Different lowercase letters in the same line indicate significant differences $(p<0.05)$.

Figure 3B shows the changes in the water distribution of croaker samples during dehydration. The grayscale values from high to low are indicated by a color scale from red to blue, respectively. A gradual decrease in the bright region of all samples could be clearly observed with the dehydration process, which meant that the water was continuously removed from the fish. There was an obvious phenomenon of uneven intensity of water in the sample for the first $9 \mathrm{~h}$, which may be due to the sublimation of ice crystals on the surface of the sample first, followed by the internal water vapor transfer to the sample surface during dehydration. It is worth noting that the water content of samples containing small ice crystals showed poor results in the first $9 \mathrm{~h}$ compared to those recorded for large ice crystals, but it had better results in the later stages, which is also observed in Section 3.1.

\subsection{Protein Oxidation}

Changes in protein structure expose sulfhydryl (SH) groups buried inside the protein, leading to the oxidation of $\mathrm{SH}$ groups, their transformation into disulfide groups, and a decrease in SH content [25]. According to the results of total SH content in Table 1, the dehydration treatment did not have a significant effect on the total SH content of myofibrillar proteins (MFP). This could be attributed to the fact that the samples were dehydrated under vacuum and isolated from oxygen, resulting in the inability of the $\mathrm{SH}$ group to be oxidized to disulfide bonds. The total SH content was found to slightly decrease in the late stage of dehydration. The aggregation occurring after protein unfolding is due to hydrophobic interactions, at which the distance between $\mathrm{SH}$ groups is shorted and the 
groups connect to form disulfide bonds, leading to a decrease in the total SH content of MFP [26]. Alternatively, it was suggested that masking of SH groups caused by protein aggregation results in a reduction in detectable total $\mathrm{SH}$ groups [27]. Therefore, the use of a freeze-dryer to freeze samples represents an approximate method to exclude the effects of protein oxidation caused by prolonged frozen storage.

\subsection{Protein Secondary Structure}

The wave number and intensity of the Raman spectrum can be used to monitor the changes of protein secondary structure [25]. The Raman spectra of large yellow croaker muscle (400-3800 $\mathrm{cm}^{-1}$ ) treated with smooth and baseline calibration are presented in Figure 4A. The amide bonds of proteins had several different modes of vibration, where the protein secondary structure ( $\alpha$-helix, random coil, $\beta$-sheet, and $\beta$-turn) is mainly investigated by amide I $\left(1600-1700 \mathrm{~cm}^{-1}\right)[16,28]$. The amide I region was selected for deconvolution and second-order derivatives, and iterative curve fitting yielded information on individual Raman peaks (Figure 4B).
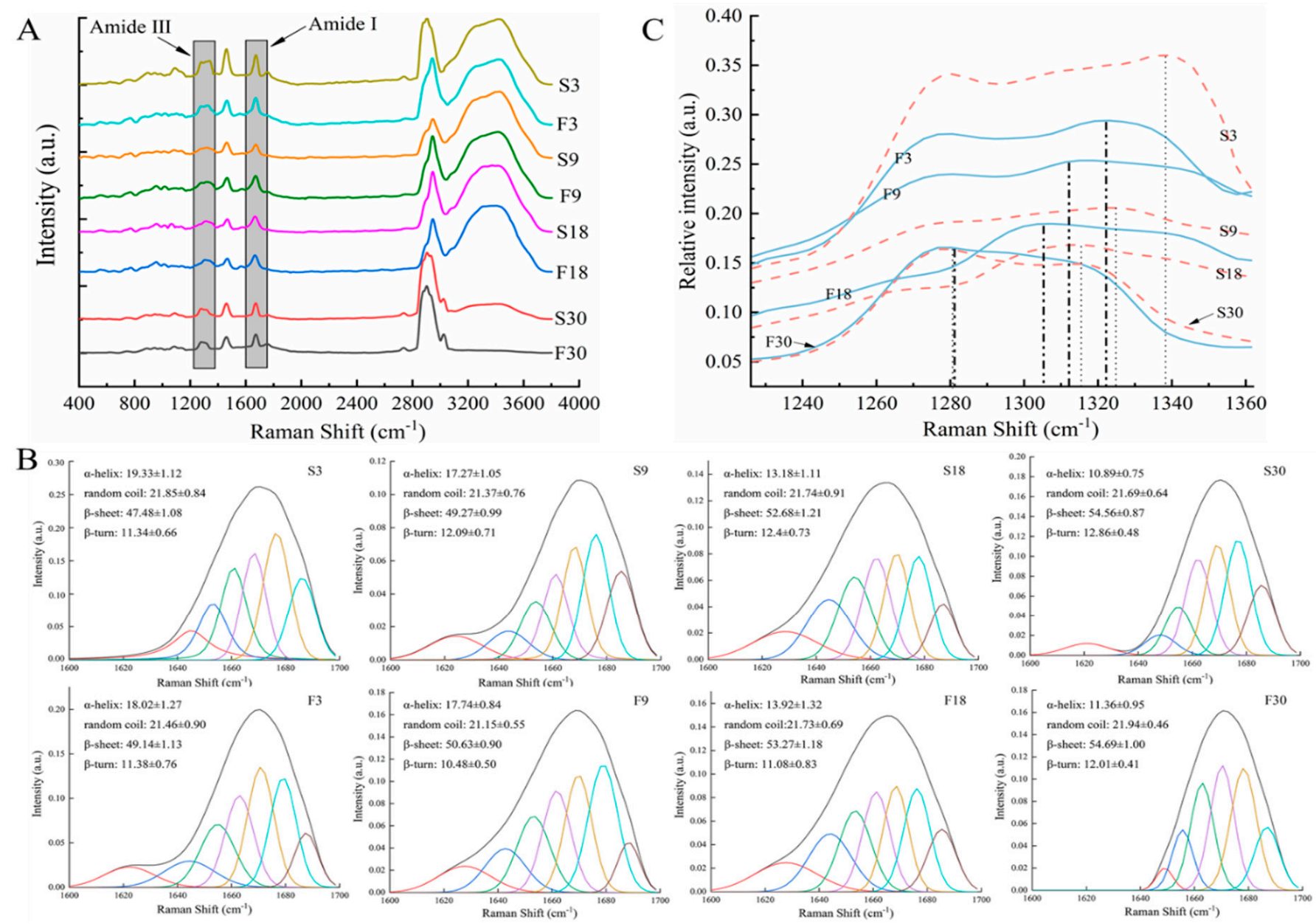

Figure 4. Effect of dehydration treatment on Raman spectra (A), iterative curve-fitted (B), and amide III region of Raman spectra (C) of thawed large yellow croakers. 
The contents of $\alpha$-helix $\left(1650-1658 \mathrm{~cm}^{-1}\right)$, random coil $\left(1660-1665 \mathrm{~cm}^{-1}\right), \beta$-sheet $\left(1665-1680 \mathrm{~cm}^{-1}\right)$, and $\beta$-turn $\left(1680-1690 \mathrm{~cm}^{-1}\right)$ could be determined from the amount of area under the peak as shown in Figure 4B [24]. Notably, $\beta$-sheet was the main protein secondary structure of samples during dehydration. The $\alpha$-helix content decreased from $19.33 \%$ to $10.89 \%$ and $18.02 \%$ to $11.36 \%$ for the slow- and fast-freezing groups. The $\beta$-sheet increased from $47.48 \%$ to $54.56 \%$ and $49.14 \%$ to $54.69 \%$ for the slow- and fast-freezing groups, respectively. However, the random coil and $\beta$-turn contents did not change significantly. This implies that dehydration may mainly lead to the unfolding of $\alpha$-helical structures and the conversion to $\beta$-sheet. The decrease in the content of $\alpha$-helical structures also meant that more hydrophobic groups were exposed due to the dehydration of sample, resulting in an increasing surface hydrophobicity [21]. Zhang et al. [16] suggested that the stability of $\alpha$-helix and $\beta$-sheet depend on the stability of hydrogen bonds within and between peptide chains, respectively. The increased $\beta$-sheet content implies an increase in hydrogen bonding, leading to enhanced protein-protein interaction [29]. Therefore, the occurrence of dehydration may lead to the breakage of intramolecular hydrogen bonds of the peptide chain, followed by the enhancement of intermolecular hydrogen bonds between peptide chains, resulting in protein aggregation. In addition, the changes in protein secondary structure at the late stage of dehydration were our focus to maintain the quality of aquatic products.

The amide III band (1230-1350 $\left.\mathrm{cm}^{-1}\right)$ is mainly generated by the $\mathrm{CN}$ stretching of the peptide bond coupled to $\mathrm{NH}$ in-plane bending vibrations, which can be used to reflect changes in the protein secondary structure [30]. Figure 4C clearly shows that the relative peak intensity of the highest Raman peak gradually decreased and the corresponding peak position moved toward the small wavenumber as the ice crystals continued to sublimate during dehydration. A decrease in the $\alpha$-helix content of fish protein was found to reveal a more intense band and a shorter wavelength [25]. Thus, dehydration caused a decrease in the $\alpha$-helix content of protein and a decrease in the stability of protein secondary conformation, which was consistent with the results obtained by amide I band analysis.

\subsection{Protein Tertiary Structure}

The changes in the protein tertiary structure can be evaluated by the number intensity of tryptophan residues and its polarity of the microenvironment measured by endogenous fluorescence spectroscopy [31]. The maximum fluorescence emission wavelength value of the fresh sample was $333.4 \pm 0.5$. When tryptophan residues buried in a hydrophobic microenvironment were exposed to a polar environment, the more hydrophilic microenvironment caused protein unfolding, resulting in a redshift (longer wavelengths) in the maximum fluorescence emission wavelength $\left(\lambda_{\max }\right)$. Nevertheless, the results presented in Figure 5A show no significant difference in the $\lambda_{\max }$ of fluorescence peak $(p>0.05)$. This suggests that the dehydration treatment could not enhance the polar environment around the increased tryptophan residues. In terms of tryptophan fluorescence intensity, the maximum fluorescence intensity $\left(\mathrm{FI}_{\max }\right)$ decreased remarkably $(p<0.05)$ with increasing dehydration time of the samples, in the order of S3, F3, S9, F9, F18, S18, F30, and S30. When tryptophan residues are mostly embedded in the core of the protein, there is a higher fluorescence intensity [32]. Thus, the action of dehydration led to protein tertiary structure unfolding. Due to the exposure of hydrophobic groups after protein unfolding, proteins tend to aggregate with each other via hydrophobic interactions [31]. This result was verified in the following for surface hydrophobicity and particle size distribution. 

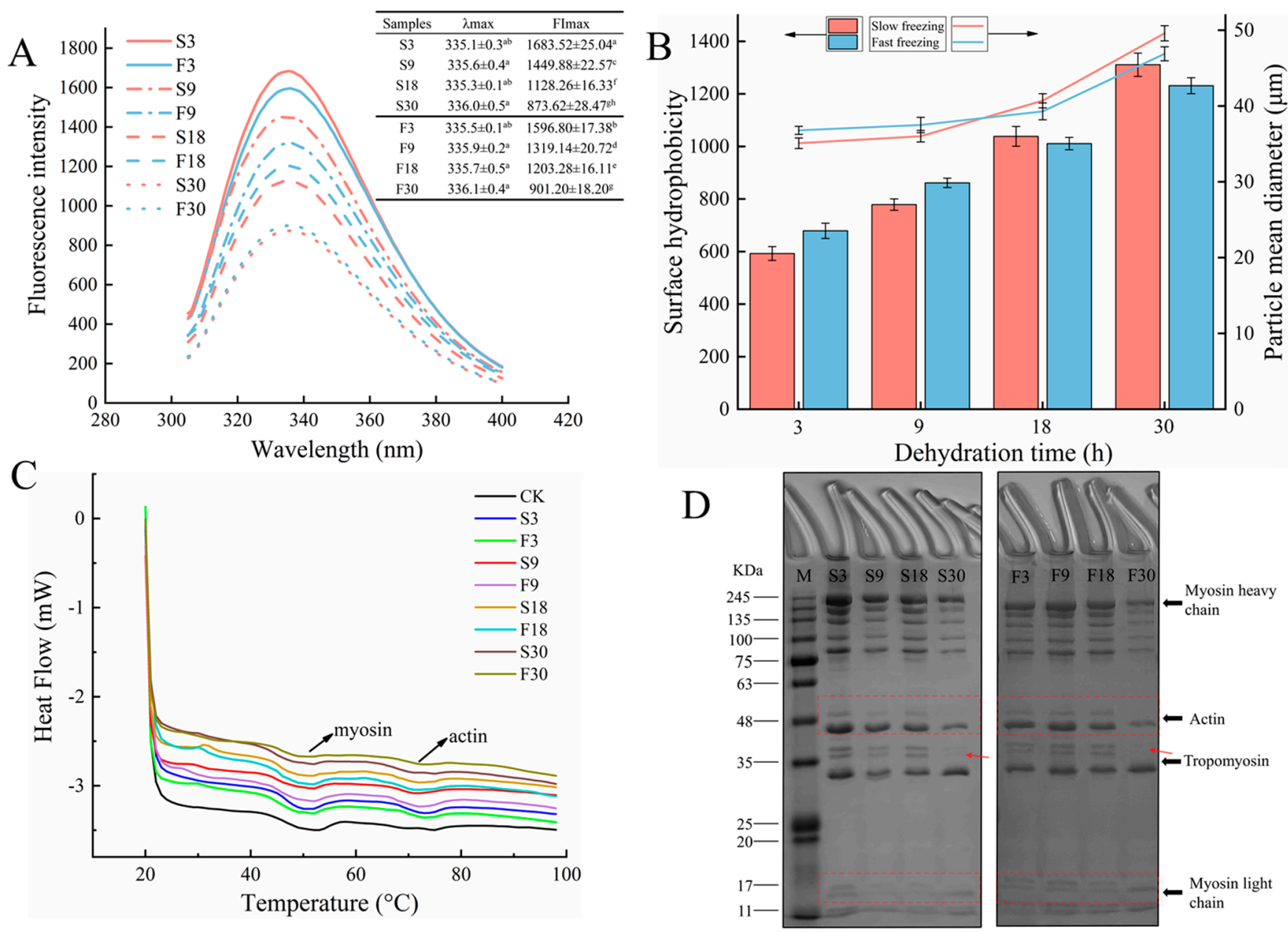

Figure 5. Effect of dehydration treatment on intrinsic fluorescence spectra (A), surface hydrophobicity and particle size (B), differential scanning calorimetry (C), and SDS-PAGE (D) of large yellow croakers. Different lowercase letters in the same index indicate significant differences $(p<0.05)$.

\subsection{MFP Aggregation}

\subsubsection{Surface Hydrophobicity}

The surface hydrophobicity $\left(\mathrm{S}_{0}\right.$-ANS) of proteins reflects the content of hydrophobic amino acid residues on the protein surface and is capable of characterizing the changes in protein conformation [33]. The $\mathrm{S}_{0}$-ANS value of the fresh sample was $316.48 \pm 36.11$. The effect of dehydration on the $\mathrm{S}_{0}$-ANS of myofibrillar proteins in large yellow croaker is depicted in Figure 5B. The gradual increase in $\mathrm{S}_{0}$-ANS values of the fast-freezing and slow-freezing groups with the increase in the dehydration time was noticeable, indicating that ice sublimation promoted myofibrillar protein unfolding and thus exposed more hydrophobic groups. Hence, dehydration induced a change in the conformation of the protein molecule. Of note, more $\mathrm{S}_{0}$-ANS was shown in the fast-freezing group compared to the slow-freezing group during the first $9 \mathrm{~h}$ of ice sublimation, while the opposite trend was observed in the later period. This was the same trend as for the water content, and it could be assumed that the dehydration of samples caused the changes in the protein molecule conformation. Zhang et al. [34] reported an increase in protein hydrophobicity in shrimp during frozen storage and attributed it to protein unfolding as well as the exposure of hydrophobic aliphatic and aromatic amino acids. The hydrophobic amino acid residues originally embedded inside the protein molecule were exposed to the protein surface, and these residues, through hydrophobic interactions, led to the onset of protein aggregation and a decrease in $\mathrm{S}_{0}$-ANS [35]. However, the $\mathrm{S}_{0}$-ANS values here showed a constant 
increase, indicating that the myofibrillar protein unfolding and aggregation had not yet reached equilibrium. The $\alpha$-helix of the myosin tail contains a large number of hydrophobic residues [36]. Therefore, the content of the $\alpha$-helix decreased after a disruption, and more hydrophobic residues were exposed, which could further verify the protein secondary structure analysis.

\subsubsection{Particle Size}

The mean particle diameter of myofibrillar proteins was used here to assess the myofibrillar protein aggregation induced by dehydration (Figure 5B). The particle size value of the fresh sample was $10.41 \pm 0.38 \mu \mathrm{m}$. The results suggested that the dehydration treatment exhibited significant differences $(p<0.05)$ in the particle mean diameters of MFP with increasing treatment time. Precisely, the observed increase in particle size after the dehydration treatment occurred mainly in the later stages of treatment. The increase in protein particle size may be due to protein aggregation caused by the oxidation and denaturation of MFP [37]. Cai et al. [32] also reported that dehydration tended to form protein aggregates. When dehydration reduces water availability, muscle proteins are exposed to solutes with higher ionic strength, and this process may lead to modifications in protein structure as evidenced by the formation of new covalent bonds and protein aggregation [4].

\subsection{Protein Thermal Stability}

Protein thermal stability is an important parameter in evaluating fish protein stability. As seen in Figure 5C, DSC thermograms of croaker muscle had two endothermic peaks, peaks 1 and 2, which appeared near $50{ }^{\circ} \mathrm{C}$ and $75^{\circ} \mathrm{C}$ and represented myosin and actin, respectively [17]. The denaturation temperature $\left(\mathrm{T}_{\max }\right)$ and denaturation enthalpy $(\Delta \mathrm{H})$ of protein showed a negative correlation with the degree of protein denaturation. According to Table 2 , the $\mathrm{T}_{\max } 1$ of samples decreased significantly $(p<0.05)$ with increasing dehydration time, but the change of $T_{\max } 2$ was not significant $(p>0.05)$, indicating that dehydration mainly caused irreversible denaturation of myosin, while actin was more stable. In addition, Rao et al. [6] found that denaturation of myosin was an important cause of water migration from the interior of lamb muscle fibers to the exterior. A decrease in $\Delta \mathrm{H}$ means that less energy is required to denature the protein and that the protein has become less stable. $\Delta \mathrm{H} 1$ decreased from 1.275 to $0.834 \mathrm{~J} / \mathrm{g}$ in the slow-freezing group, while it decreased from 1.129 to $0.855 \mathrm{~J} / \mathrm{g}$ in the fast-freezing group; therefore, dehydration led to a reduction in energy necessary to resist myosin denaturation and a decrease in myosin stability, especially for samples containing large ice crystals in the later stages of dehydration. The decrease in the protein thermal stability may be a result of the breakage of hydrogen bonds between protein molecules caused by water loss, resulting in the degradation of protein structure and the formation of protein aggregation $[26,38]$.

\subsection{SDS-PAGE Analyses}

SDS-PAGE was used to characterize the effect of dehydration treatment on the degradation of MFP by determining the molecular weight (Figure 5D). The appearance of myosin heavy chains (MHC, bout $200 \mathrm{kDa}$ ) may be due to cross-linking and aggregation of myofibril proteins, and the appearance of myosin light chains (MLC, 14-21 kDa) may be caused by the degradation of heavy chains [39]. As shown in Figure 5D, the protein molecules of the croaker samples frozen and dehydrated for $18 \mathrm{~h}$ did not change significantly. The samples containing large or small ice crystals, nevertheless, showed the disappearance of actin $(45 \mathrm{kDa})$, tropomyosin $(38 \mathrm{kDa})$, and MLC bands after $30 \mathrm{~h}$ of dehydration, which indicated the appearance of breaks in protein covalent bonds and primary structure [16]. Simultaneously, there was a slight decrease in the intensity of the MLC band, probably due to protein degradation and fragmentation or aggregation caused by the high activity of histoproteases [25]. The results of SDS-PAGE indicated that significant protein degradation occurred when the water content of the sample decreased to a certain level. 
Table 2. $\mathrm{T}_{\max }$ and $\Delta \mathrm{H}$ values obtained of myosin and actin of large yellow croaker muscle during dehydration.

\begin{tabular}{ccccc}
\hline \multirow{2}{*}{ Sample } & \multicolumn{2}{c}{ Myosin } & \multicolumn{2}{c}{ Actin } \\
\cline { 2 - 5 } & $\mathbf{T}_{\max } \mathbf{1}\left({ }^{\circ} \mathbf{C}\right)$ & $\Delta \mathbf{H 1}(\mathbf{J} / \mathbf{g})$ & $\mathbf{T}_{\max } \mathbf{2}\left({ }^{\circ} \mathbf{C}\right)$ & $\Delta \mathbf{H} \mathbf{~ ( J / g )}$ \\
\hline CK & $54.04 \pm 0.45^{\mathrm{a}}$ & $1.611 \pm 0.01^{\mathrm{a}}$ & $74.52 \pm 0.30^{\mathrm{a}}$ & $0.506 \pm 0.014^{\mathrm{b}}$ \\
S3 & $49.94 \pm 0.25^{\mathrm{b}}$ & $1.275 \pm 0.012^{\mathrm{b}}$ & $71.75 \pm 0.23^{\mathrm{b}}$ & $0.550 \pm 0.012^{\mathrm{ab}}$ \\
S9 & $48.80 \pm 0.18^{\mathrm{d}}$ & $1.122 \pm 0.012^{\mathrm{c}}$ & $71.10 \pm 0.18^{\mathrm{bc}}$ & $0.572 \pm 0.004^{\mathrm{a}}$ \\
S18 & $48.10 \pm 0.30^{\mathrm{e}}$ & $0.947 \pm 0.008^{\mathrm{e}}$ & $70.59 \pm 0.75^{\mathrm{c}}$ & $0.498 \pm 0.006^{\mathrm{b}}$ \\
S30 & $47.26 \pm 0.41^{\mathrm{f}}$ & $0.834 \pm 0.014^{\mathrm{gh}}$ & $70.72 \pm 0.16^{\mathrm{c}}$ & $0.517 \pm 0.012^{\mathrm{b}}$ \\
\hline F3 & $49.42 \pm 0.13^{\mathrm{c}}$ & $1.129 \pm 0.009^{\mathrm{c}}$ & $71.35 \pm 0.20^{\mathrm{b}}$ & $0.564 \pm 0.008^{\mathrm{ab}}$ \\
F9 & $48.31 \pm 0.49^{\mathrm{de}}$ & $0.968 \pm 0.010^{\mathrm{d}}$ & $71.47 \pm 0.16^{\mathrm{b}}$ & $0.535 \pm 0.014^{\mathrm{b}}$ \\
F18 & $48.05 \pm 0.24^{\mathrm{e}}$ & $0.923 \pm 0.006^{\mathrm{f}}$ & $71.23 \pm 0.42^{\mathrm{b}}$ & $0.472 \pm 0.010^{\mathrm{c}}$ \\
F30 & $47.68 \pm 0.19^{\mathrm{f}}$ & $0.855 \pm 0.013^{\mathrm{e}}$ & $71.51 \pm 0.35^{\mathrm{b}}$ & $0.485 \pm 0.003^{\mathrm{c}}$ \\
\hline
\end{tabular}

Values are mean \pm standard deviation. Different lowercase letters in the same line indicate significant differences $(p<0.05)$.

\section{Conclusions}

This study effectively explored the effects of dehydration on water migrating property and protein changes in large yellow croaker during frozen storage. A freeze-dryer was to accelerate experiments, isolate samples from oxygen, and exclude the effects of protein oxidation and ice recrystallization during frozen storage. Based on the variation of sample weight loss and water content, the results indicated that the ice sublimation of samples containing small ice crystals was faster in the early stage of dehydration compared to that of samples containing large ice crystals, while the water loss was hindered in the later stage because of the resistance of small pore size to water vapor flow. The significant decrease in $T_{2}$ values indicated that water mobility gradually decreased as the water content of samples decreased. Meanwhile, the decrease in bound water content caused by dehydration reflects the aggregation and conformational changes of proteins. However, the total SH content showed only a slight decrease. As determined by Raman spectrometry and intrinsic fluorescence, a decrease in $\alpha$-helix content and fluorescence intensity and an increase in $\beta$-sheet content were induced by dehydration, demonstrating that protein secondary and tertiary structures were destroyed during the dehydration process. Increasing surface hydrophobicity and particle size indicated that ice sublimation caused exposure of the hydrophobic groups and aggregation of myofibrillar proteins during dehydration. Additionally, the results of DSC and SDS-PAGE revealed that dehydration led to a decrease in thermal stability of proteins and an increase in MFP degradation, especially irreversible denaturation of myosin. Therefore, avoiding dehydration is important to maintain the quality of large yellow croakers during frozen storage. This study provides a theoretical basis for delaying the dehydration of aquatic products during frozen storage. In addition, temperature fluctuations are inevitable during frozen storage and further understanding of their effect on the dehydration rate is important.

Author Contributions: M.T.: conceptualization, formal analysis, data curation, writing-original draft, review and editing. J.X.: conceptualization, funding acquisition, supervision, writingoriginal draft, review and editing. All authors have read and agreed to the published version of the manuscript.

Funding: This research was financially supported by the National Key R\&D Program of China (2019YFD0901604), the Key Project of Science and Technology Commission of Shanghai Municipality (19DZ1207503), and the Shanghai Professional Technology Service Platform on Cold Chain Equipment Performance and Energy Saving Evaluation (19DZ2284000). All authors have read and agreed to the published version of the manuscript.

Institutional Review Board Statement: Not applicable.

Informed Consent Statement: Not applicable. 
Data Availability Statement: All relevant data are included in the article.

Acknowledgments: We would like to thank the anonymous reviewers for the helpful comments and suggestions.

Conflicts of Interest: The authors declare no conflict of interest.

\section{References}

1. Dalvi-Isfahan, M.; Jha, P.K.; Tavakoli, J.; Daraei-Garmakhany, A.; Xanthakis, E.; Le-Bail, A. Review on identification, underlying mechanisms and evaluation of freezing damage. J. Food Eng. 2019, 255, 50-60. [CrossRef]

2. Tan, M.; Wang, J.; Li, P.; Xie, J. Storage time prediction of glazed frozen squids during frozen storage at different temperatures based on neural network. Int. J. Food Prop. 2020, 23, 1663-1677. [CrossRef]

3. Zhu, Z.; Zhou, Q.; Sun, D.-W. Measuring and controlling ice crystallization in frozen foods: A review of recent developments. Trends Food Sci. Technol. 2019, 90, 13-25. [CrossRef]

4. Zhang, M.; Li, F.; Diao, X.; Kong, B.; Xia, X. Moisture migration, microstructure damage and protein structure changes in porcine longissimus muscle as influenced by multiple freeze-thaw cycles. Meat Sci. 2017, 133, 10-18. [CrossRef]

5. Mulot, V.; Benkhelifa, H.; Pathier, D.; Ndoye, F.-T.; Flick, D. Measurement of food dehydration during freezing in mechanical and cryogenic freezing conditions. Int. J. Refrig. 2019, 103, 329-338. [CrossRef]

6. Rao, W.L.; Wang, Z.Y.; Shen, Q.W.; Li, G.X.; Song, X.; Zhang, D.Q. LF-NMR to explore water migration and water-protein interaction of lamb meat being air-dried at 35 degrees C. Dry. Technol. 2018, 36, 366-373. [CrossRef]

7. Wang, J.; Yu, W.; Xie, J. Effect of Glazing with Different Materials on the Quality of Tuna During Frozen Storage. Foods 2020, 9, 231. [CrossRef]

8. Hottot, A.; Vessot, S.; Andrieu, J. Freeze drying of pharmaceuticals in vials: Influence of freezing protocol and sample configuration on ice morphology and freeze-dried cake texture. Chem. Eng. Process. Process Intensif. 2007, 46, 666-674. [CrossRef]

9. Jin, J.; Yurkow, E.J.; Adler, D.; Lee, T.-C. Improved freeze drying efficiency by ice nucleation proteins with ice morphology modification. Food Res. Int. 2018, 106, 90-97. [CrossRef]

10. Tan, M.; Mei, J.; Xie, J. The Formation and Control of Ice Crystal and Its Impact on the Quality of Frozen Aquatic Products: A Review. Crystals 2021, 11, 68. [CrossRef]

11. Kumar, P.K.; Rasco, B.A.; Tang, J.; Sablani, S.S. State/Phase Transitions, Ice Recrystallization, and Quality Changes in Frozen Foods Subjected to Temperature Fluctuations. Food Eng. Rev. 2020, 12, 421-451. [CrossRef]

12. Li, L.; Zhang, M.; Song, X.; Wang, W.; Bhandari, B. Changes in unfrozen water content and dielectric properties during pulse vacuum osmotic dehydration to improve microwave freeze-drying characteristics of Chinese yam. J. Sci. Food Agric. 2019, 99, 6572-6581. [CrossRef]

13. Tan, M.; Li, P.; Yu, W.; Wang, J.; Xie, J. Effects of Glazing with Preservatives on the Quality Changes of Squid during Frozen Storage. Appl. Sci. 2019, 9, 3847. [CrossRef]

14. Lan, W.; Hu, X.; Sun, X.; Zhang, X.; Xie, J. Effect of the number of freeze-thaw cycles number on the quality of Pacific white shrimp (Litopenaeus vannamei): An emphasis on moisture migration and microstructure by LF-NMR and SEM. Aquac. Fish. 2020, 5, 193-200. [CrossRef]

15. Nian, L.; Cao, A.; Cai, L.; Ji, H.; Liu, S. Effect of vacuum impregnation of red sea bream (Pagrosomus major) with herring AFP combined with CS@ $\mathrm{Fe}_{3} \mathrm{O}_{4}$ nanoparticles during freeze-thaw cycles. Food Chem. 2019, 291, 139-148. [CrossRef]

16. Zhang, Z.; Yang, Y.; Zhou, P.; Zhang, X.; Wang, J. Effects of high pressure modification on conformation and gelation properties of myofibrillar protein. Food Chem. 2017, 217, 678-686. [CrossRef]

17. Liu, S.; Zeng, X.; Zhang, Z.; Long, G.; Lyu, F.; Cai, Y.; Liu, J.; Ding, Y. Effects of Immersion Freezing on Ice Crystal Formation and the Protein Properties of Snakehead (Channa argus). Foods 2020, 9, 411. [CrossRef] [PubMed]

18. Wang, X.-Y.; Xie, J. Evaluation of water dynamics and protein changes in bigeye tuna (Thunnus obesus) during cold storage. LWT 2019, 108, 289-296. [CrossRef]

19. Zhang, B.; Zhao, J.-L.; Chen, S.-J.; Zhang, X.-L.; Wei, W.-Y. Influence of trehalose and alginate oligosaccharides on ice crystal growth and recrystallization in whiteleg shrimp (Litopenaeus vannamei) during frozen storage with temperature fluctuations. Int. J. Refrig. 2019, 99, 176-185. [CrossRef]

20. Geidobler, R.; Winter, G. Controlled ice nucleation in the field of freeze-drying: Fundamentals and technology review. Eur. J. Pharm. Biopharm. 2013, 85, 214-222. [CrossRef]

21. Zhang, J.; Zhou, D.; Zhong, X.; Pei, Z.; Tian, Y.; Xiang, D.; Cao, J.; Shen, X.; Li, C. Quality and protein degradation of golden pompano (Trachinotus blochii) fillets during four drying methods. LWT 2020, 130, 109638. [CrossRef]

22. Cheng, S.; Tang, Y.; Zhang, T.; Song, Y.; Wang, X.; Wang, H.; Wang, H.; Tan, M. Approach for monitoring the dynamic states of water in shrimp during drying process with LF-NMR and MRI. Dry. Technol. 2018, 36, 841-848. [CrossRef]

23. Song, Y.; Zang, X.; Kamal, T.; Bi, J.; Cong, S.; Zhu, B.; Tan, M. Real-time detection of water dynamics in abalone (Haliotis discus hannai Ino) during drying and rehydration processes assessed by LF-NMR and MRI. Dry. Technol. 2018, 36, 72-83. [CrossRef]

24. Cai, L.; Cao, M.; Cao, A.; Regenstein, J.; Li, J.; Guan, R. Ultrasound or microwave vacuum thawing of red seabream (Pagrus major) fillets. Ultrason. Sonochemistry 2018, 47, 122-132. [CrossRef] 
25. Cai, L.; Nian, L.; Cao, A.; Zhang, Y.; Li, X. Effect of Carboxymethyl Chitosan Magnetic Nanoparticles Plus Herring Antifreeze Protein on Conformation and Oxidation of Myofibrillar Protein From Red Sea Bream (Pagrosomus major) After Freeze-Thaw Treatment. Food Bioprocess Technol. 2020, 13, 355-366. [CrossRef]

26. Wang, B.; Kong, B.; Li, F.; Liu, Q.; Zhang, H.; Xia, X. Changes in the thermal stability and structure of protein from porcine longissimus dorsi induced by different thawing methods. Food Chem. 2020, 316, 126375. [CrossRef]

27. Benjakul, S.; Visessanguan, W.; Thongkaew, C.; Tanaka, M. Comparative study on physicochemical changes of muscle proteins from some tropical fish during frozen storage. Food Res. Int. 2003, 36, 787-795. [CrossRef]

28. Gao, W.; Huang, Y.; Zeng, X.-A.; Brennan, M.A. Effect of soluble soybean polysaccharides on freeze-denaturation and structure of myofibrillar protein of bighead carp surimi with liquid nitrogen freezing. Int. J. Biol. Macromol. 2019, 135, 839-844. [CrossRef]

29. Shao, J.-H.; Zou, Y.-F.; Xu, X.-L.; Wu, J.-Q.; Zhou, G.-H. Evaluation of structural changes in raw and heated meat batters prepared with different lipids using Raman spectroscopy. Food Res. Int. 2011, 44, 2955-2961. [CrossRef]

30. Xiong, G.; Han, M.; Kang, Z.; Zhao, Y.; Xu, X.; Zhu, Y. Evaluation of protein structural changes and water mobility in chicken liver paste batters prepared with plant oil substituting pork back-fat combined with pre-emulsification. Food Chem. 2016, 196, 388-395. [CrossRef]

31. Li, F.; Wang, B.; Kong, B.; Shi, S.; Xia, X. Decreased gelling properties of protein in mirror carp (Cyprinus carpio) are due to protein aggregation and structure deterioration when subjected to freeze-thaw cycles. Food Hydrocoll. 2019, 97, 105223. [CrossRef]

32. Cai, L.; Zhang, W.; Cao, A.; Cao, M.; Li, J. Effects of ultrasonics combined with far infrared or microwave thawing on protein denaturation and moisture migration of Sciaenops ocellatus (Red drum). Ultrason. Sonochemistry 2019, 55, 96-104. [CrossRef]

33. Sun, Q.; Chen, Q.; Xia, X.; Kong, B.; Diao, X. Effects of ultrasound-assisted freezing at different power levels on the structure and thermal stability of common carp (Cyprinus carpio) proteins. Ultrason. Sonochemistry 2019, 54, 311-320. [CrossRef]

34. Zhang, B.; Fang, C.-D.; Hao, G.-J.; Zhang, Y.-Y. Effect of kappa-carrageenan oligosaccharides on myofibrillar protein oxidation in peeled shrimp (Litopenaeus vannamei) during long-term frozen storage. Food Chem. 2018, 245, 254-261. [CrossRef]

35. Zou, Y.; Xu, P.; Wu, H.; Zhang, M.; Sun, Z.; Sun, C.; Wang, D.; Cao, J.; Xu, W. Effects of different ultrasound power on physicochemical property and functional performance of chicken actomyosin. Int. J. Biol. Macromol. 2018, 113, 640-647. [CrossRef]

36. Higuera-Barraza, O.A.; Torres-Arreola, W.; Ezquerra-Brauer, J.M.; Cinco-Moroyoqui, F.J.; Rodríguez Figueroa, J.C.; Marquez-Ríos, E. Effect of pulsed ultrasound on the physicochemical characteristics and emulsifying properties of squid (Dosidicus gigas) mantle proteins. Ultrason. Sonochemistry 2017, 38, 829-834. [CrossRef]

37. Li, F.; Wang, B.; Liu, Q.; Chen, Q.; Zhang, H.; Xia, X.; Kong, B. Changes in myofibrillar protein gel quality of porcine longissimus muscle induced by its stuctural modification under different thawing methods. Meat Sci. 2019, 147, 108-115. [CrossRef]

38. Saeed, S.; Howell, N.K. Rheological and differential scanning calorimetry studies on structural and textural changes in frozen Atlantic mackerel (Scomber scombrus). J. Sci. Food Agric. 2004, 84, 1216-1222. [CrossRef]

39. Zhu, W.; Li, Y.; Bu, Y.; Li, J.; Li, X. Effects of nanowarming on water holding capacity, oxidation and protein conformation changes in jumbo squid (Dosidicus gigas) mantles. LWT 2020, 129, 109511. [CrossRef] 